\title{
A Preliminary Documentation of the Coral Reefs from Libya
}

\author{
Belkasim Khameiss ${ }^{1}$, William Hoyt ${ }^{2}$, Saad K. El Ebaidi ${ }^{3}$, Ahmed M. Muftah ${ }^{3}$, James Klaus ${ }^{4}$, \\ Ann Budd5 \\ ${ }^{1}$ Department of Geological Sciences, Ball State University, Muncie, IN, USA \\ ${ }^{2}$ Earth and Atmospheric Sciences, University of Northern Colorado, Greeley, CO, USA \\ ${ }^{3}$ Department of Earth Sciences, Faculty of Science, University of Benghazi, Benghazi, Libya \\ ${ }^{4}$ Department of Geological Science, University of Miami, Coral Gables, FL, USA \\ ${ }^{5}$ Department of Geoscience, University of lowa, lowa City, IA, USA \\ Email: *Bkb28_1981@yahoo.com
}

Received 4 February 2016; accepted 18 April 2016; published 21 April 2016

Copyright (C) 2016 by authors and Scientific Research Publishing Inc.

This work is licensed under the Creative Commons Attribution International License (CC BY). http://creativecommons.org/licenses/by/4.0/

\section{(c) (i) Open Access}

\begin{abstract}
Corals studies in Libya are very limited, although they play an important role in the oil exploration as they form excellent reservoirs of coral reef buildups at some oil fields of Sirt Basin (e.g. Intisar "Idris" and Sahabi Fields). Both fields are produced from Paleocene coral reefs. Meanwhile, in Cyrenaica, corals are of less importance as they are not reported in subsurface tertiary rocks, which probably in the environmental settings of these sediments out of the core of reef as occurred in the surface. Meanwhile, corals are reported from older (Jurassic) subsurface successions as in Concession NC-152, but the cementation diagenesis leads to blocking and destroying the porosity. This study presents the first surface documentation work of eight scleractinian coral species from the exposed sediments in northern Libya, where sixtaxa is reported from Al Jabal al Akhdar region, these include a) an association of huge colonies of Caulastrea sp. and Stylophora sp., from the Middle Eocene Darnah Formation at West Darnah road cut section. Theco-existence of the fast Caulastrea sp. with the slow Stylophora sp. is due to the competition strategy; b) Antiguastrea sp. which is reported from the Oligocene Algal Limestone of Al Bayda Formation at Daryanah-Abyar Roadcut section; c) Cyphastrea sp. and Aleveopora sp. from Oligo-Miocene Al Faidiyah Formation at Al Fatayah cement quarry and d) Tarbellastraea sp. From Middle Miocene Benghazi Formation at Benghazi Cement Quarry. In addition, two species Astraeaopora sp. and Actinacis paroraiare reported from the Upper Miocene sediments of formation "M" in As Sahabi area.
\end{abstract}

\section{Keywords}

Cyrenaica Corals, Benghazi Cement Quarry, Persististrombus coronatus

\footnotetext{
*Corresponding author.
}

How to cite this paper: Khameiss, B., Hoyt, W., El Ebaidi, S.K., Muftah, A.M., Klaus, J. and Budd, A. (2016) A Preliminary Documentation of the Coral Reefs from Libya. Open Journal of Geology, 6, 260-269. 


\section{Introduction}

This paper deals with corals built up in the Cyrenaica. Coral refers to coral carbonate accumulation which has original topographic relief that lives in association with other organisms including algae and foraminifers as major contributor Guilcher [1]. The differential pattern in these associations seems to be controlled by both the paleo-relief and the eustatic sea level [1].

The documented subsurface coral occurrences in Libya are very limited and are mainly obtained from the oil exploration activities, where coralreef forms an excellent reservoir as evidenced from some previous reports of oil fields in Sirt Basin (e.g. Intisar "Idris”) [2]. Examples are the reefal buildups (Rugose/cup coral with encrusted coralline red algae with excellent biomoldic porosity due to leaching as in Gheriat Formation along the eastern edge in Kutla graben in Sirt Basin [3]. The older Jurassic branching cup corals with the interior skeleton are completely filled with calcite cement and lime-mud matrix resulted in blocking the porosity, which are occasionally reported from the base of core \#7(16199') in Well A1-NC152 by [4].

However, the most comprehensive surface coral occurrences in the previous works that are presented by [5] who report about fifty species of corals, mostly of scleractinian type, from the oligocene sections of Umm ad Dahiy Formation, Abu Hashish Formation, Ar Rahlah Member of Maradah Formation and Al Khums Formation from Al Hufrah and Ar Raqubah Oil fields in Sirt Basin. Among the most important reef-builders species include Madracis decaphylla, Stylophora parvistella, S. thirsiformis, Monticulastraea ex gr. daedalea, Athecastraea maradahensis, Astraeopora decaphylla, Agathiphyllia gregaria and Actinacis rollei.

\section{Locations}

The studied corals are obtained from two regions:

1) The Al Jabal al Akhdar region which is located in northern Cyrenaica. It is a huge anticlinorium extending in SW-ENE ridge located between $32^{\circ}$ to $33^{\circ} \mathrm{N}$ and latitudes and $20^{\circ}$ to $23^{\circ} \mathrm{E}$ longitudes. The documented corals herein are from four well known localities, these are: a) West Darnah Roadcut section; b) Daryanah-Abyar Roadcut section; c) Al Fatayah cement quarry; iv) Benghazi (Hawari) cement Quarry in Figure 1.

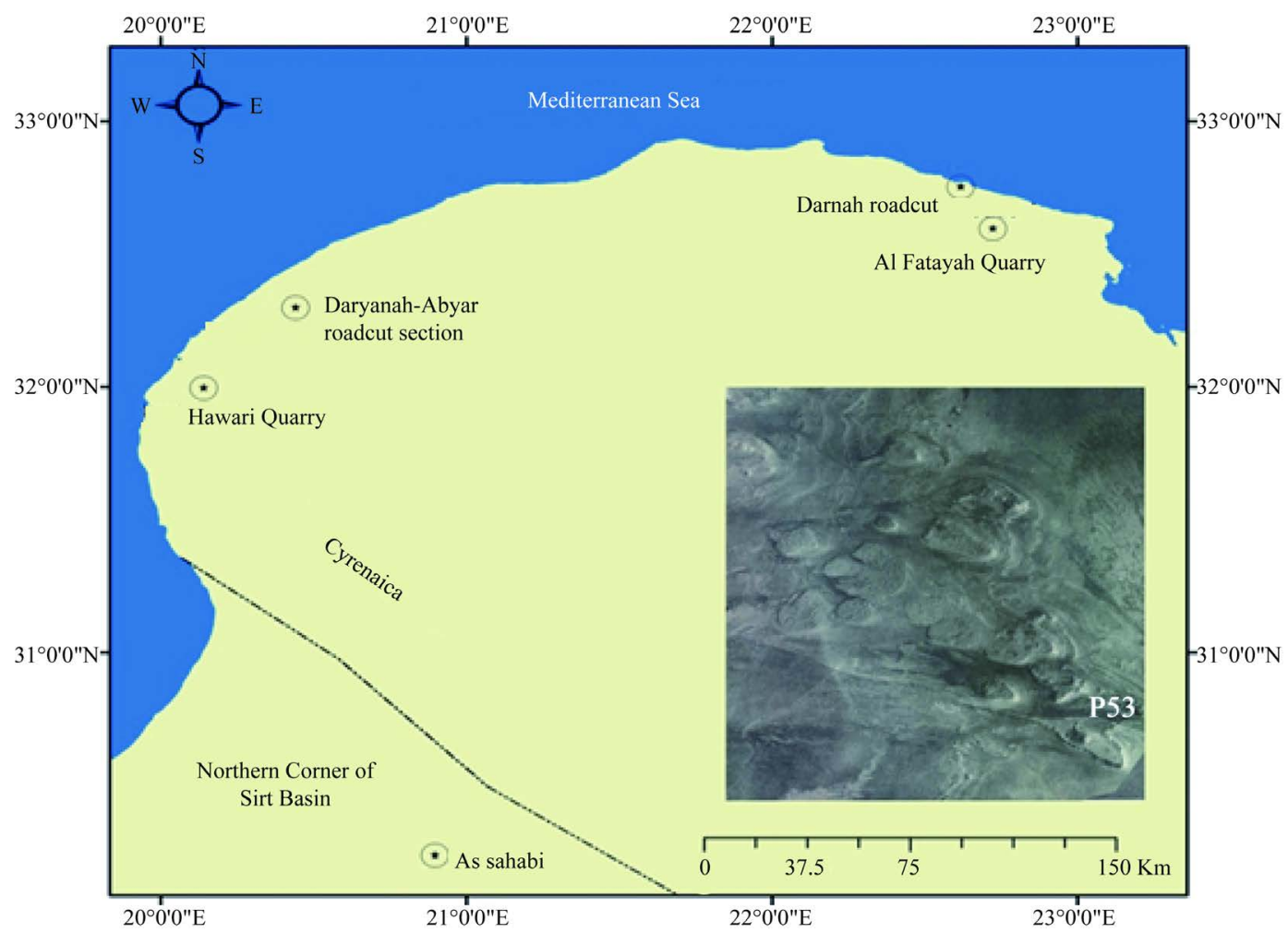

Figure 1. Location map of the studied coral-exposures in Northeast Libya, with As Sahabi "in the vicinity of P53” aerial photograph shows the coral patches [6]. 
2) The As Sahabi region, which is located in the northeastern corner of Sirt Basin, covering an area of about $375 \mathrm{~km}^{2}$. It is bounded by longitudes $20^{\circ} 48^{\prime} 08^{\prime \prime}$ to $20^{\circ} 54^{\prime} 45^{\prime \prime} \mathrm{E}$ and latitudes $30^{\circ} 10^{\prime} 58^{\prime \prime}$ to $30^{\circ} 17^{\prime} 36^{\prime \prime} \mathrm{N}$, within a tectonic province called the Ajdabiyah Trough. The documented coral specimens came from the scattered clusters of patch coral reef P53 and P119 area at the western edge of the Sabkhat al Qunayy in Figure 1.

\section{Stratigraphic Background}

The Al Jabal al Akhdar area in Cyrenaica region, northeastern Libya has a long geologic history, ranging from the Paleozoic to Late Miocene. The tertiary exposed rocks in this area are represented by nine rock units separated from each other by unconformity surfaces in Figure 2, these are from bottom to top as follows:

1) Al Uwayliah Formation composes of chalky limestone, soft and enriched with planktic and calcareous nannofossils of Landenian age at its upper exposed section, However, it is well bedded and hard with rare planktic foraminifers of Danian age at its lower exposed part, although its middle part is not exposed, a series problem in the definition of Al Uwayliah Formation, this issue was discussed by [7]. There are no reefal facies in this formation [8] [9].

2) Apollonia Formation is a well bedded chalky limestone, of mudstone-wackestone texture, with common chert nodules. The foraminifers are indicative of Ypresian — Lutetian age. There are no reefal facies in this formation. This formation exhibits interfingering relationship with the overlying Darnah Formation.

3) Darnah Formation is a thick bedded to massive limestone of grainstone to Packstone locally becoming rudstone in texture, this Formation is enriched in larger benthic foraminifers (Nummulites, Discocyclina, Orbitolites, Sphaerogypsina, etc.) with coralline red algae and/or coral facies at some places. This formation is dated as Middle Eocene based on the Nummulites gizehensis as example. Corals are among the local bioclasts occurrence as in West Darnah Roadcut section.

4) Shahhat Marl is dated as Late Eocene based on the presence of Nummulites fabianii and Gaziryinabulchellus [10]. There are no reefal facies in this formation [8].

5) Al Bayda Formation, the lower member "Algal Limestone Member" of Al Bayda Formation [11] [12]. It consists of algal limestone enriched in red algae and thick oysters with some Nummulites fichteli and N. vascus [13]. This formation yields common corals enough to make reef at several places [14]-[17].

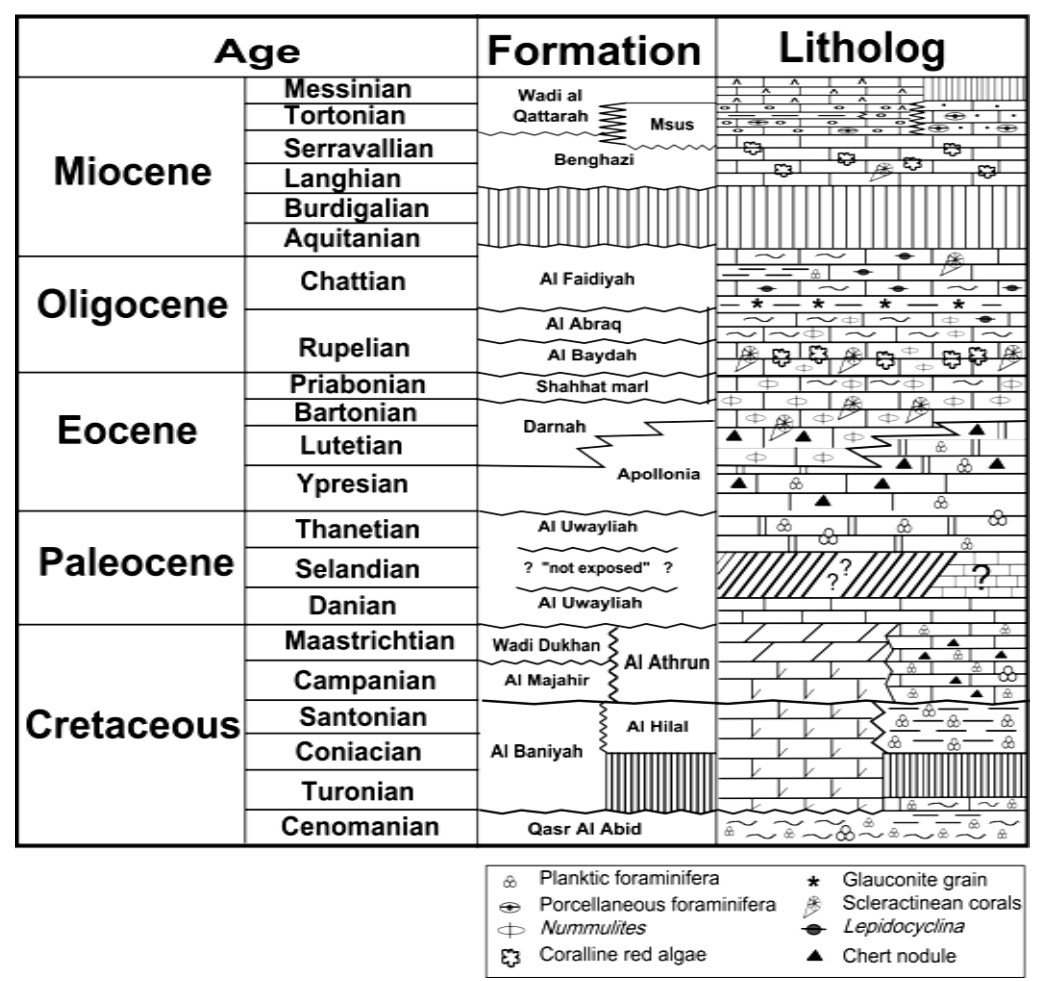

Figure 2. Stratigraphic chart of the exposed rock units in Al Jabal al Akhdar, NE Libya. 
6) Al Abraq Formation is dated as Middle-Late Oligocene, it is skeletal limestone with abundant Operculinacomplanata africana and Lepidocuclina spp. It is deposited under shoal-channel complex [12]. There are no reefal facies in this Formation [17] [18].

7) Al Faidiyah Formation is dated as Late Oligocene-Early Miocene which was updated by [12] to be Miocene age. Hence the age dating of this formation is still enigmatic. Lithologically, it is gradually changed upwards from glauconitic marl to skeletal marl and Limestone. Corals are among the reported local bioclasts in Al Fatayah Quarry section.

8) Benghazi Formation is dated as Early-Middle Miocene [11] [12] [19]. It consists of massive fossiliferous limestone, made of fine crystalline, hard, enriched in red algae. Amphistegina sp., and Miogypsina globula indicated a depositional settings under shallow marine of mid ramp setting [20], which is interrupted with lagoonal facies as interpreted by the occurrence of the peloidal-miliolidfacies [14] [17].

Wadi al Qattarah Formation is dated Late Miocene [12]. It is composed of thin bedded of oolitic/peloidal grainstones with highly cross bedded at some levels changed upward to evaporitic facies with common giant gypsum crystals which referred to the Mediterranean salinity crisis during the Messinian [12] [21].

\section{Stratigraphy of As Sahabi Area}

The As Sahabi area according to Muftah [1] consists of four superimposed rock units separated from each other by disconformity surface, these are from bottom to top:

a) Formation "M" (Tortonian); it consists of semi-consolidated bioclasts exposed in the floor of the Sebkhat, totally or partially decalcified and gypsified. Erosional relief of shallow Miocene coral reef, echinoids Clypeaster and Echinolampas and pelecypods, gastropods, bryozoans and Balanus.

b) Formation "P" (Messinian); it consists of lattice of gypsum crystals in a very sparse mineral matrix of dark sand and clay with very few fossils.

c) Sahabi Formation (Messinian-Pliocene); it was subdivided into six members:

i) Member “T”. It consists of cross bedded sand with abundant marine fauna and trace fossils (e.g. Ophiomorpha).

ii) Member T.X. Reddish clay and vertisol with cracks accessible in one area only.

iii) Member U-1. Sands with clay lenses and clay balls incorporating with common well preserved bones, teeth, jaws and skulls of land mammals.

iv) Member U-D. Cross bedded and bioturbated sandy dolostone.

v) Member U-2. Interbeddedsand and clay with dolomitic crusts with mammals remains.

vi) Member V. Sands and sandy clays with lenses of dolomite and gypsum crystals common root casts.

d) Formation "Z" (Pleistocene) is the youngest formation and consists of very complex fossil soil with paleo-caliche and terrestrial snail (e.g. Helix sp.).

\section{Cyrenaican Coral Reef}

The collected coral specimens used in this study are mainly derived from four localities located in the North east Libya (Cyrenaica) and one locality in As Sahabi area in Figure 1. These are 1) Benghazi Cement Quarry section where, one species has been collected from Benghazi Formation (Middle Miocene); 2) Al Fatayah cement Quarry section, where, one species has been collected from Al Faidiyah Formation (Late Oligocene); 3) West Darnah Roadcut section, where three species have been collected from Darnah Formation (Middle Eocene); 4) Daryanah-Abyar Roadcut section, where one species has been collected from the Algal Limestone Member of Al Bayda Formation (Early Oligocene); 5) As Sahabi where, two species have been collected from formation "M" (Late Miocene). The documented coral reefs from these localities are listed below in chronostratigraphical order.

\subsection{Eocene Reef}

The Eocene rocks of Al Jabal al Akhdar in Figure 2 are composed of two formations, the older Apollonia Formation, which was deposited in open marine waters as suggested by the planktic foraminifers and the mudstone textured facies as well as the presence of chert nodules with sponge spicules? The upper Darnah Formation on the other hand are deposited in more shallower neritic water with warm water conditions allowing to the accu- 
mulation and growth of the Nummulites (nummulitic bank) and corals (coral reef) at some areas such the vicinity of Darnah city (West Darnah Roadcut section Lat. 32 $53^{\circ} 00^{\prime \prime N}$ and long. $21^{\circ} 55^{\prime} 01^{\prime \prime E}$ ). At this section, two species are documented the species are left as open named because more statistical work needed for the future work. The Caulastrea sp. (Figure 3 and Figure 4(A)-(B)) dominates the colony as it is considered the fast growing coral over the low growing Stylophora sp. (Figure 4(B)-(C) and Figure 5).

\subsection{Oligocene Reef}

The Oligocene rocks of Al Jabal al Akhdar in Figure 2 are composed of two formations, the older Al Baydah Formation, which was deposited in mid ramp waters as suggested by the common presence of larger benthic foraminifers in addition to common red algae and coral Antiquastrea sp. in Figure 6. The documented coral reef in Al Bayda Formation played an important role in the development of the caves and dolines and other small scale karstic features in the area [14] [15] [21].

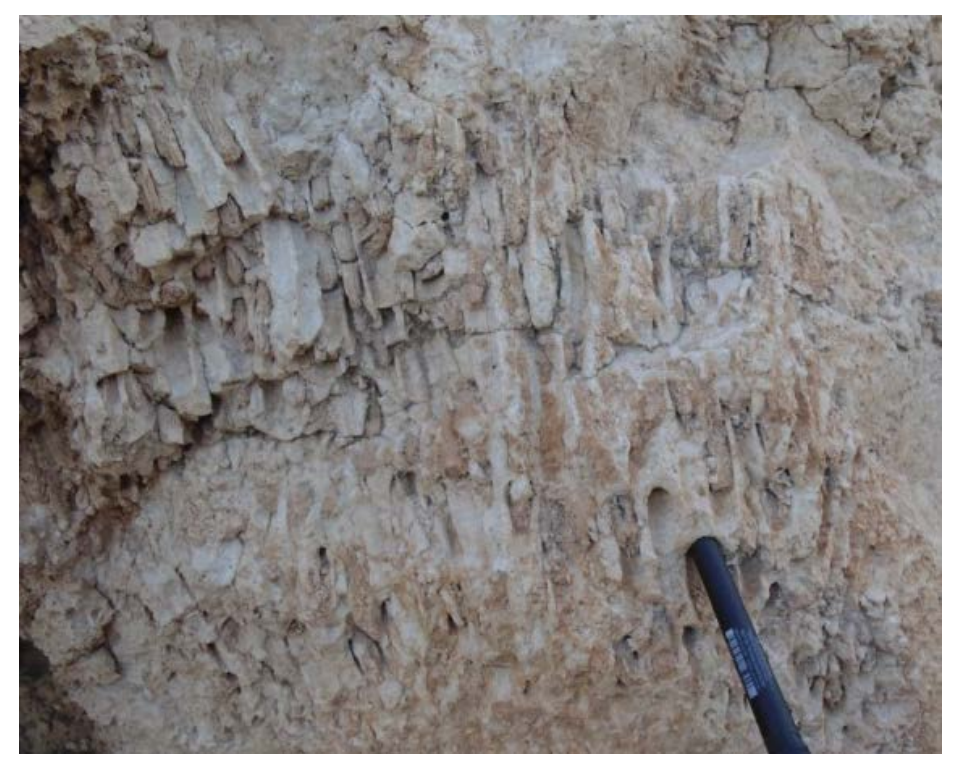

Figure 3. Close-up view of Caulastrea sp. at West Darnah Roadcut section.

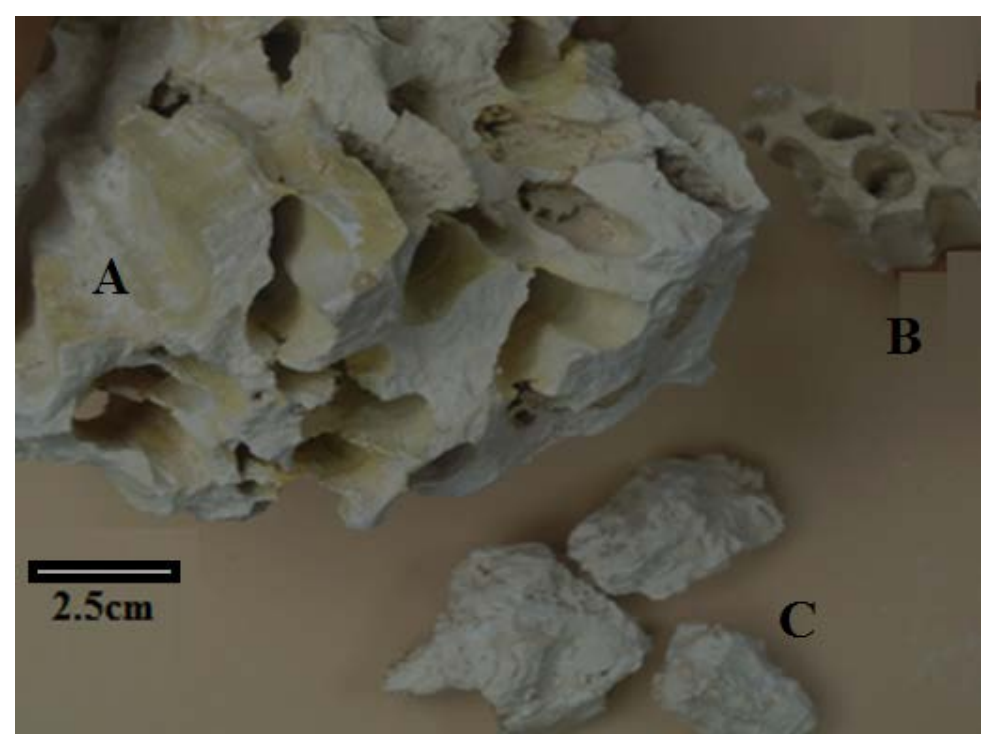

Figure 4. (A) Caulastrea sp.; (B) Caulastrea with Stylophora sp.; and (C) Stylophora sp. at West Darnah Roadcut. 


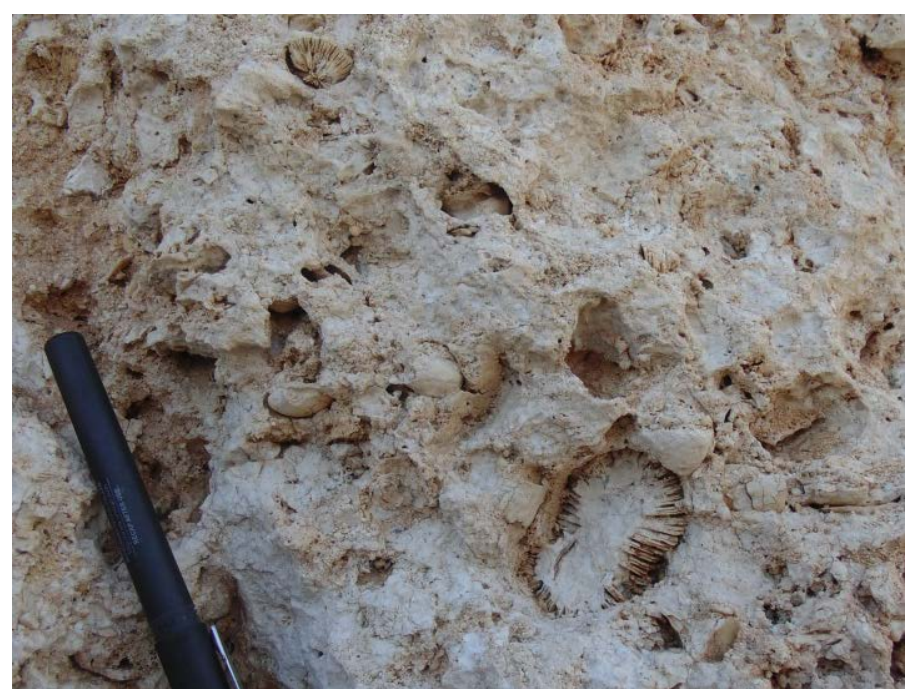

Figure 5. Close-up view of Stylophora sp. at West Darnah Roadcut section.

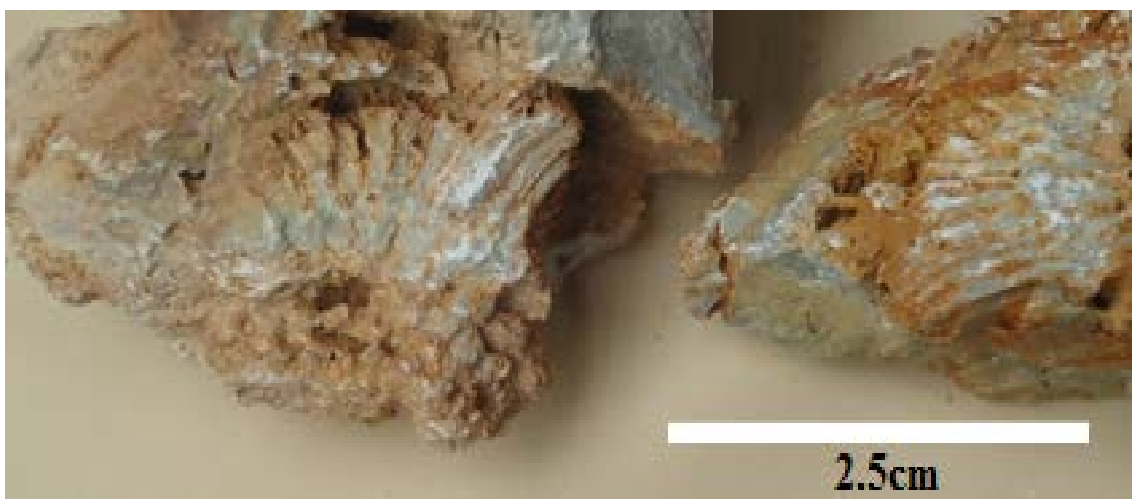

Figure 6. Coral species Antiguastrea sp. from Al Baydah Formation at Daryanah-Al Abyar raod-cut.

\subsection{Upper Oligocene Reef}

The reef framework in Upper Oligocene Al Faidiyah Formation at Al Fatayah cement quarry is constructed of two genera of corals Cyphastrea sp. Figure 7(A) band Aleveopora sp, and Figure 8(A)-(B) with encrusted red algae, shell fragments, bryozoans and larger foraminifers (nummulitids and lepidocyclinids).

\subsection{Miocene Reef (Al Jabal al Akhdar, Cyrenaica)}

The Miocene Tarbellastraea sp. coral of Benghazi Formation in Figure 9 is reported locally at Benghazi (Al Hawari) Cement Quarry.

\subsection{Miocene Reef (As Sahabi Area)}

The As Sahabi coral reef is mainly of scleractinian type. They are growing in forms of small scale patch reefs extending parallel to the western edge of Sabkhat al Qunayyin, in NNE-SSW trending pattern. The diversity of the As Sahabi corals is very low, restricted to only two species in the Tortonian formation "M". The first type is Astraeaopora sp. Figure 10(A) and Figure 11(A) bit is completely replaced by gypsum at some levels. The other coral type present in As Sahabi is Actinacis parorai, shown here in (Figure 10(B) and Figure 11(C)-(D)). It is closely similar to the specimen figured by [5] from the Rupelian Wadi Ar Rijl in Al Hufra Oil field of Sirt Basin. It was previously misidentified as Stromatolites [22]. In addition to rare occurrences of encrusted coral growing on Persististrombuscoronatus as substrate in Figure 12(A)-(B). 


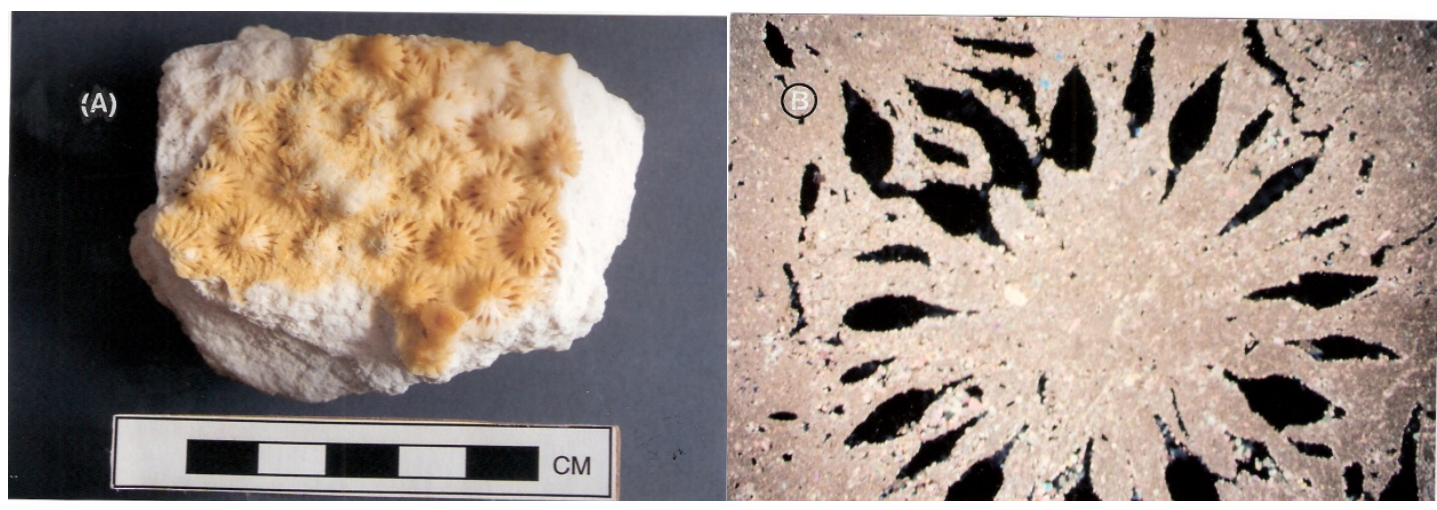

Figure 7. (A) Cyphastrea sp. from Al Faidiyah Formation at Al Fatayah Quarry, (B) Thin section from the same colony shows mouldic porosity (in black). Field of view $=6 \mathrm{~mm},(\mathrm{XPL})$.
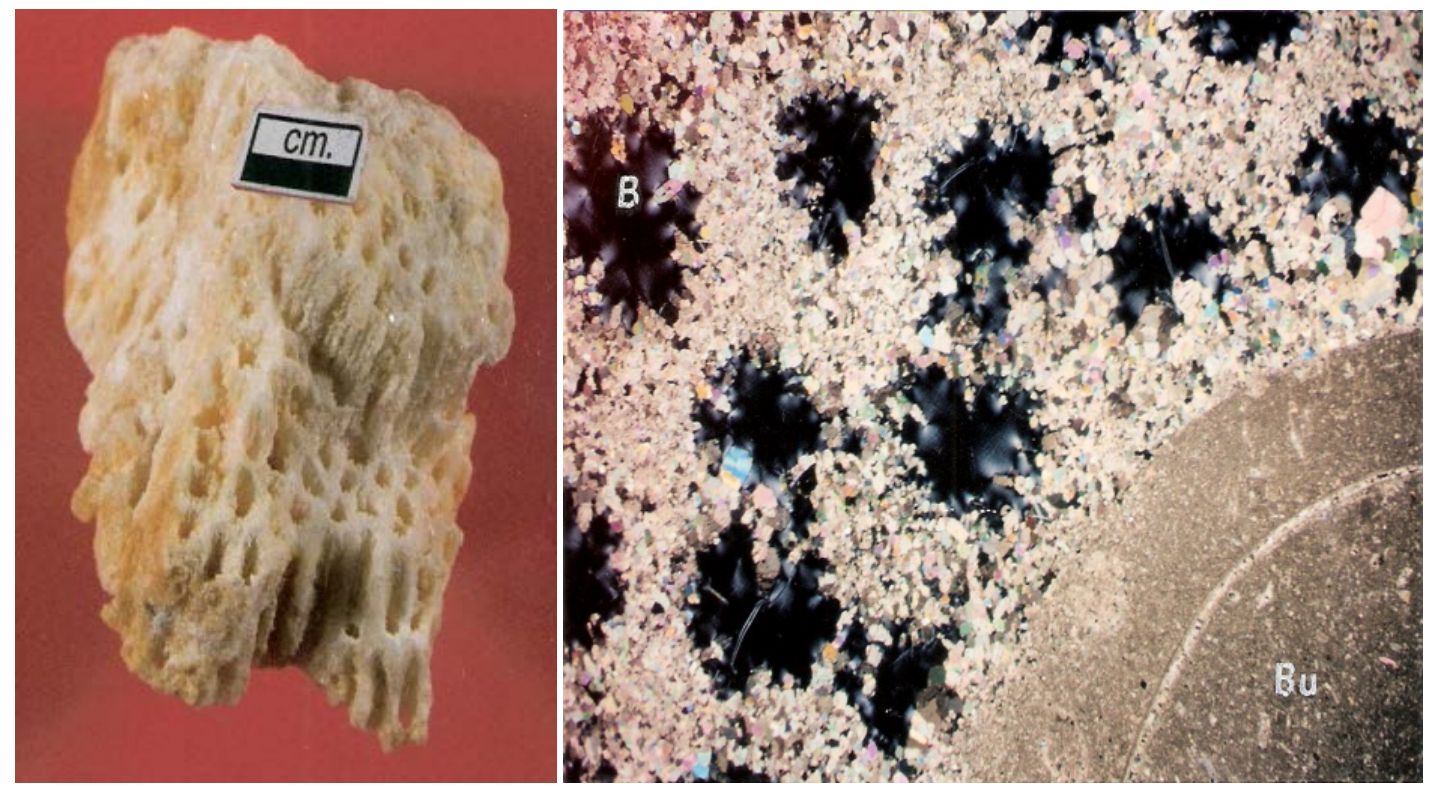

Figure 8. (A) Aleveopora sp. from Al Faidiyah Formation at Al Fatayah Quarry, (B) thin section from the same colony shows boring by bivalves $(\mathrm{Bu})$ mouldic porosity (in black). Note: Wall has been replaced by Calcite. Field of view $=6 \mathrm{~mm}$, (XPL).
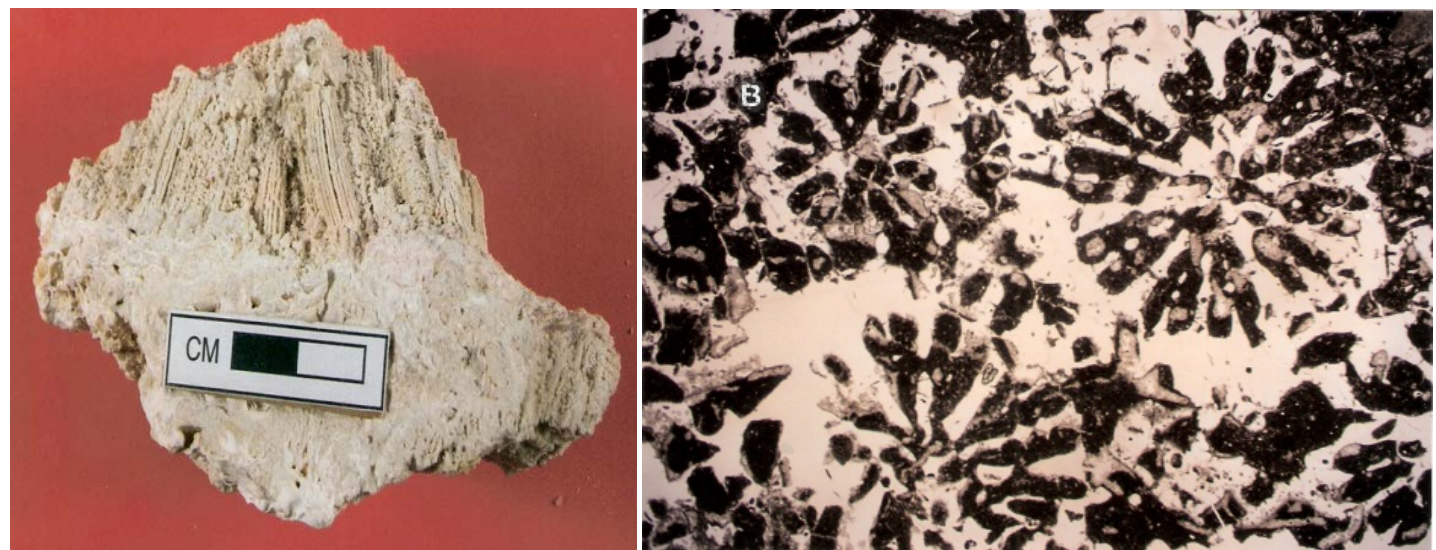

Figure 9. (A) Tarbellastraea sp. from Benghazi Formation at Benghazi (Al Hawari) Cement Quarry, (B) Thin section from the same colony shows mouldic porosity (in black). Field of view $=6 \mathrm{~mm}$, (XPL). 


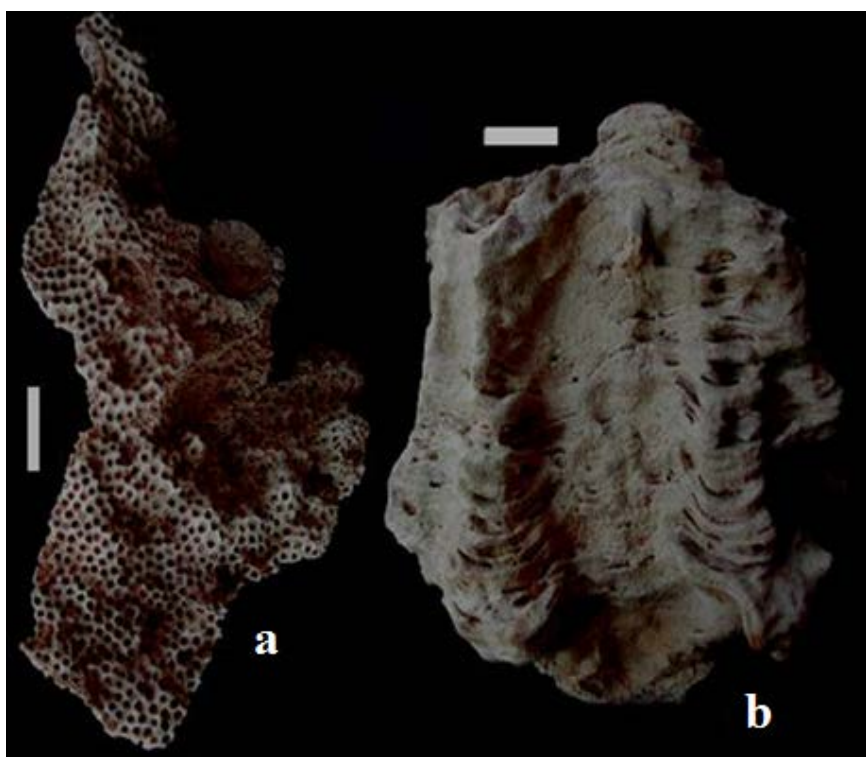

Figure 10. (a) Astraeaopora sp., (b) Actinacis parorai (Bar scale = 2 cm), As Sahabi area.

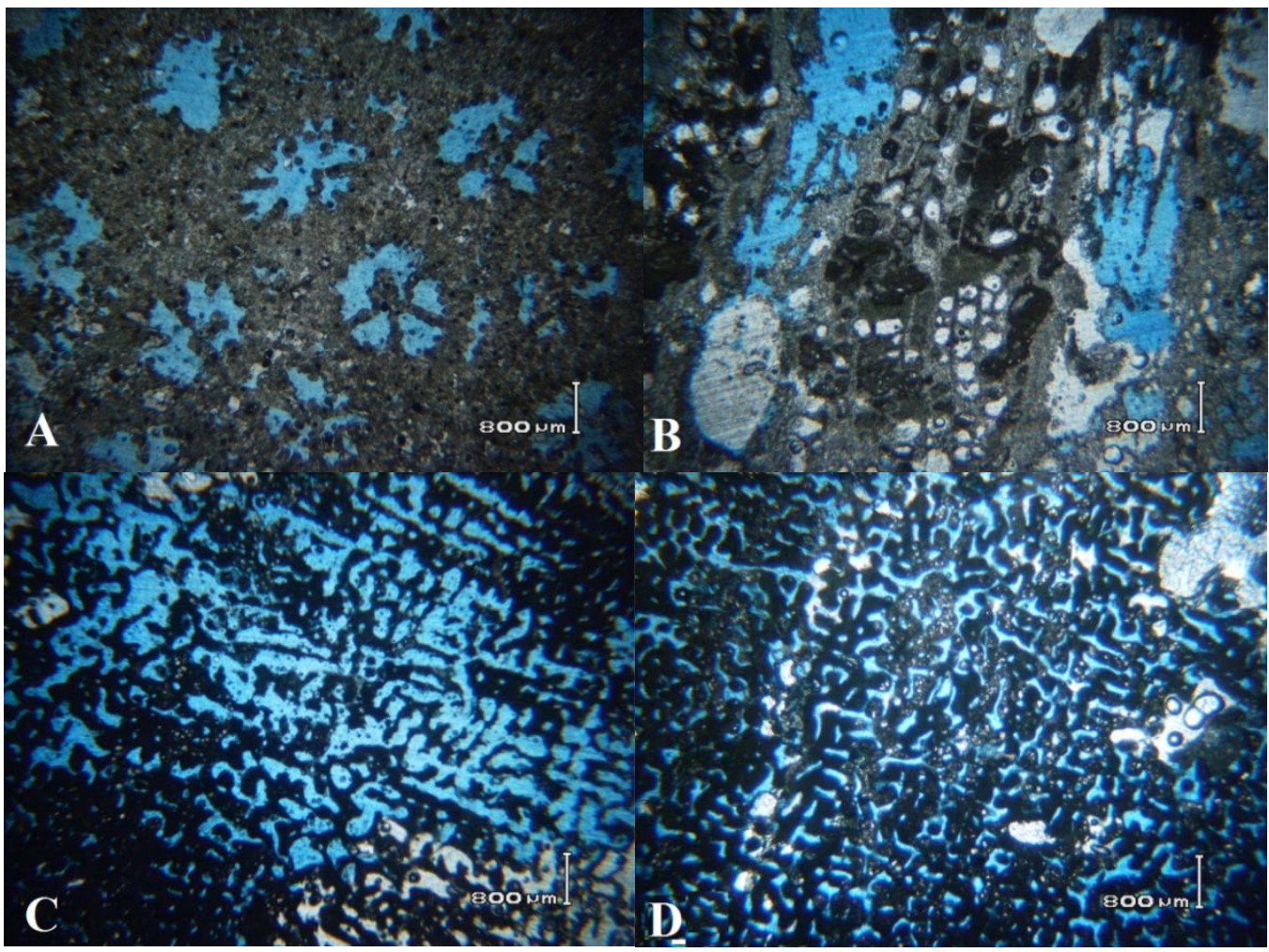

Figure 11. (A)-(B) Astraeaopora sp., (A) Transverse section and (B) Longitudinal section. (C)-(D) Actinacis parorai: (C) Transverse section and (D) Longitudinal section.

\section{Conclusions}

The Al Jabal al Akhdar area and As Sahabi area display conspicuous exposures of the scleractinian coral reef. Only eight species are documented herein, six from The Al Jabal al Akhdar area and two from the As Sahabi area.

The reefal facies of Al Jabal al Akhdar is restricted to the Middle Eocene Darnah Formation, Early Oligocene 


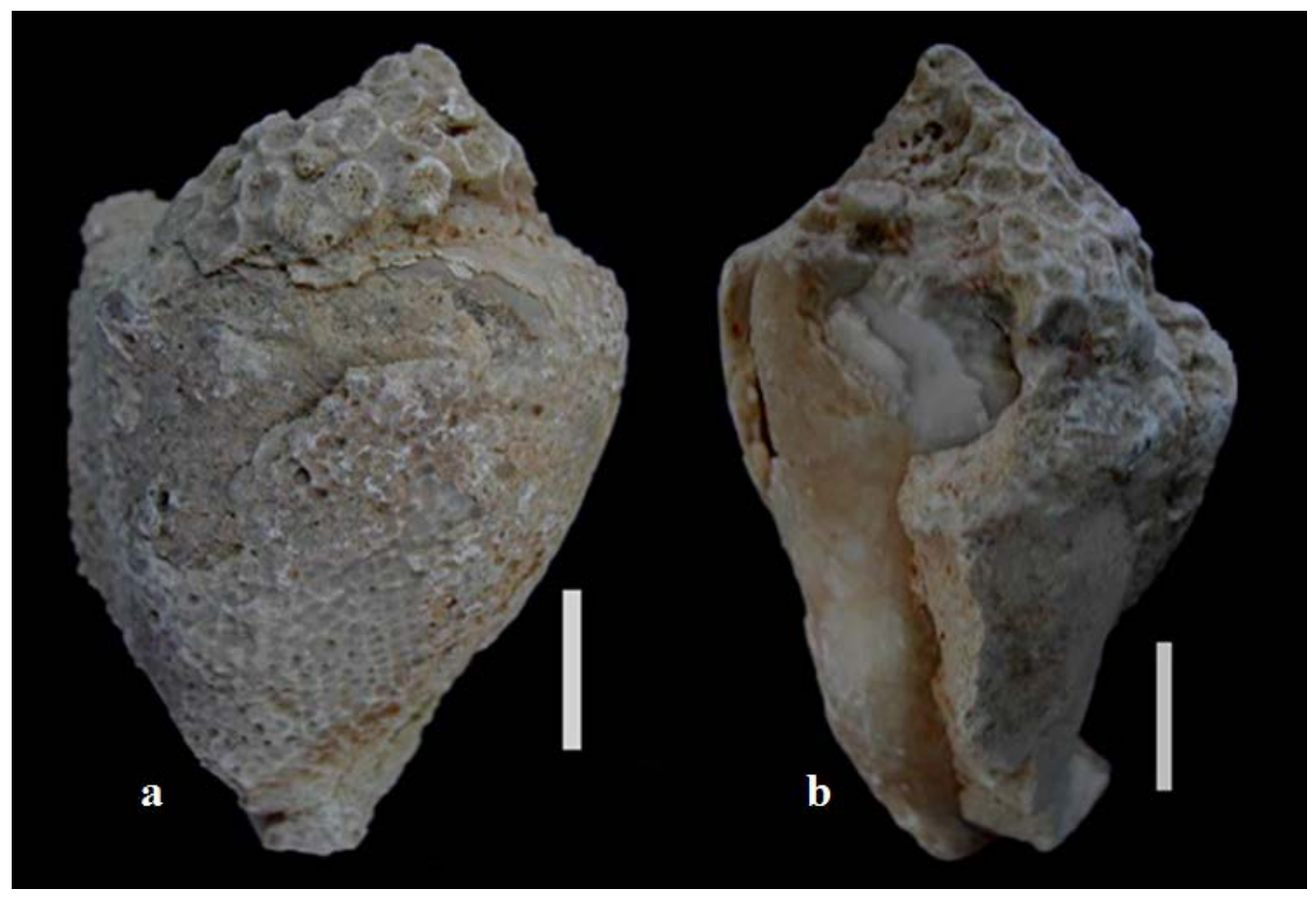

Figure 12. (a)-(b) Encrusted corals on Persististrombuscoronatu. (Bar scale $=2 \mathrm{~cm}$ ).

Al Bayda Formation; Upper Oligocene Al Faidiyah Formation and Middle Miocene Benghazi Formation. Only the Upper Miocene formation " $M$ " is developed in As Sahabi area.

Diagenetic processes at some subsurface records rule the effectiveness of coral buildups to be good reservoirs, although in the surface show excellent porosity and permeability.

\section{Acknowledgements}

We would like to thank the Arabian Gulf Oil Company in Ganfouda for their assistance in sample preparation and providing some subsurface data. The authors wish to thank the University of Benghazi for the logistical support during field trips. Dr. James Pollard of the University of Manchester is appreciated for the identification of Oligo-Miocene coral specimens.

\section{References}

[1] Guilcher, A. (1988) Coral Reef Geomorphology. John Wiley \& Sons Ltd., Chichester, New York, Brisbane, Toronto, and Sigapore, $228 \mathrm{p}$.

[2] Brady, T.J., Campbell, N.D.J. and Maher, C.E. (1980) Intisar "D” Oil Field, Libya. In: Illing, L.V. and hodbson, G.D., Eds., Giant Oil and Gas Field of the Decade 1968-1978, AAPG Mem., London, 543-564.

[3] Addaloush, A.H., Muftah, A.M. and Daniel, H.J. (2003) Lithofacies, Paleonenvironment and Diagensis of Gheriat Formation Sequences along the Eastern Edge of Kutla Graben, Sirt Basin, Libya. 5th International Conference on the Geologt of the Middle East, Cairo, 11 May 2003, 299-306.

[4] Daniels, H., Thusu, B., Bu Argoub, F. and Muftah, A. (1993) Sedimentological Analysis of Cored Qagash, Sirwal and Jurassic Intervals in Well A1-NC152, NE Libya. Internal AGOCO Report, 14 p.

[5] Hladil, J., Otava, J. and Galle, A. (1991) Oligocene Carbonate Buildups of the Sirt Basin, Libya. In: Salem, M.J., Hammuda, O.S. and Eliagoubi, B.A., Eds., The geology of Libya, IV, 1401-1420.

[6] Boaz, N.T., El-Arnauti, A., Gaziry, A.W., De Heinzelin, J. and Dechant Boaz, D. (1987) Neogene Paleontology and Geology of Sahabi. Alan R. Liss, New York, 401 p.

[7] Tmalla, A.F.A. (2007) The Stratigraphic Positions of the Wadi Dukhan and Al Uwayliah Formations, Northeast Libya- 
a Review. Scripta Geologica, 134. 119-130.

[8] Khameiss, B.K. and William, H. (2013) Coastal Environmental and Engineering Studies, Northeastern Libya. The 3rd International Geography Symposium, Kemer Antalya, 86.

[9] Khameiss, B.K., Abdelfatah Hamed, A.L. Hdhireia, Z. and Nour Alden, A.L. (2015) Geological Tourism Northeast Libya. AEG 58 Annual Meeting 2015, Pittsburgh, 67.

[10] Muftah, A.M. (2013) Biostratigraphic and Temporal Relations between the Neogene Sahabi and Maradah Formations, Cibya. Contribution to the Age Determination of Their Contained Mammalian Paleofaunas. (Unpublished) PhD Thesis, University of Athens, 225 p.

[11] El Hawat, A.S. and Abdulsamad, E.O. (2004) The Geology of Cyrenaica: A Field Seminar. Geology of East Libya, Field Trip, ESSL, Tripoli, Libya, 130 p.

[12] El Hawat, A.S. and Shelmani, M.A. (1993) Short Notes and Guidebook on the Geology of Al Jabal al Akhdar, Cyrenaica, NE Libya. Inprinted Limited Malta, $70 \mathrm{p}$.

[13] Muftah, A.M. and Erhoma, A.H. (2002) Coralline Red Algae of the Algal Limestone Member of Al Bayda Formation, NE Libya: Biostratigraphic and Paleoenvironmental Significance. In: El-Sayed, A.A. and Yousef, P., Eds., 6th International Conference on the Geology of the Arab World, Cairo, 14 August 2002, 633-638.

[14] Khameiss, B.K. (2012) Coastal Marine Engineering in Benghazi City, NE Libya Poster Presentation Academic Excellence Week 2012. University of Northern, Colorado, 38.

[15] Khameiss, B.K. (2012) Marine Reef and Age Dating of Tertiary Section, Northern Eastern Libya. Colorado Scientific Society Conference 2012, Boulder, 17 May 2012, 3-4.

[16] Khameiss, B.K. (2013) Middle Tertiary Reefs in Northeastern Libya: Fossil Clues to Dating and Paleoenvironments. Graduate Geology (MSC) Unpublished Thesis, University of Northern Colorado, 22-45.

[17] Khameiss, B.K. (2015) Karatic Distribution between Wadi Aljubiah and Wadi AL Bakurarea. AEG 58 Annual Meeting 2015, Pittsburgh, 16 April 2015, 67.

[18] Khameiss, B.K. and William, H. (2013) Distribution of Miocene Echinoderm Species as a Tool for Paleoenvironmental Interpretation; Northeast Libya. Ice and Their World Fossils Conference 2016, Poster, 12.

[19] De Heinzelin, J. and El-Arnauti, A. (1987) The Sahabi Formation and Related Deposits. In: Boaz, N., El-Arnauti, A., Gaziry, A., De Heinzelin, J. and Boaz, D.D., Eds., Neogene Paleontology and Geology of Sahabi, Alan R. Liss, New York, 1-21.

[20] Hassan, S.H. and Muftah, A.M. (2008) Lithofacies Study of Al Bayda Formation, Al Jabal al Akhdar, NE Libya. In: Salem, M.J., El-Arnauti, A. and El Sogher Saleh, A., Eds., The Geology of East Libya, Elsevier, Amsterdam, 337-344.

[21] Muftah, A.M., Abdulsamad, E.O., Ali, R.A. and Alsanusi, A.H. (2010) Stratigraphy-Karst Relationships in the Eocene-Miocene Carbonates of Al Jabal al Akhdar, (Cyrenaica, NE Libya). SpeleolgiaIblea, 14, 53-60.

[22] De Heinzelin, J. and El-Arnauti, A. (1982) Stratigraphy and Geological History of the Sahabi and Related Formations. Garyounis Scientific Bulletin, 4, 5-12. 